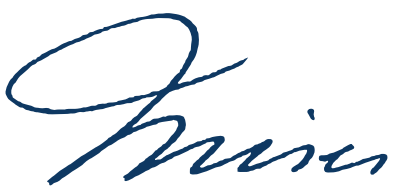

\title{
Entrepreneurship and Equilibrium
}

Ying Tang ${ }^{I}$ (D) 0000-0001-9597-4008

Shenzhen University - Shenzhen - China

Walter E. Block ${ }^{I I}$ (1) 0000-0003-2215-4791

Loyola University - New Orleans - Louisiana - United States

David Gordon ${ }^{I I I}$ (i) 0000-0002-9764-1968

The Mises Institute - Auburn - Alabama - United States

\begin{abstract}
Neoclassic economic theory regards equilibrium, whether general or partial, as a crucially important foundation of the dismal science. In the view of mainstream economists, the general equilibrium framework offers not only an investigation of the economy in terms of its perfect qualities, but is also suitable as an end or goal of action. In contrast, the Austrian school sees equilibrium (or the evenly rotating economy - ERE) merely as a direction towards which economic activities tend to move, but that is never attained. Praxeological economics has thus concentrated not on equilibrium, but on the market process towards it. Since the process of shifting resources to meet these ends cannot be achieved spontaneously, entrepreneurship plays a key role. In Mises' and Rothbard's view, entrepreneurship involves uncertainty bearing, going beyond the alertness Hayek and Kirzner emphasize. On the other hand, unlike Lachmann, who looks at the economy as a kaleidoscope and rejects the ERE, Mises and Rothbard regard it as an indispensable tool in understanding the economy.
\end{abstract}

Keywords: Evenly Rotating Economy, praxeology, entrepreneurship, Market process, equilibrium.

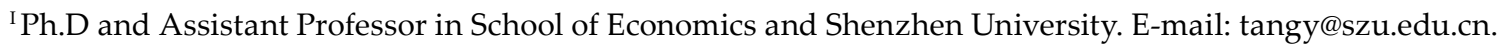

${ }^{\text {II }}$ Ph.D at Harold E. Wirth Eminent Scholar Endowed Chair and Professor of Economics in Loyola University New Orleans. E-mail: wblock@loyno.edu.

III Ph.D and Senior Fellow in Mises Institute. E-mail: dgordon@mises.org. 


\title{
Empreendedorismo e Equilíbrio
}

\begin{abstract}
Resumo: A teoria econômica neoclássica considera o equilíbrio, seja geral ou parcial, como base fundamental da ciência sombria. Na visão dos economistas do mainstream, a estrutura do equilíbrio geral oferece, não apenas oferece uma análise da economia em termos de suas qualidades perfeitas, mas também é adequada como fim ou objetivo de ação. Em contraste, a Escola Austríaca considera o equilíbrio (ou a economia uniformemente circular - ERE) apenas como a direção para a qual as atividades econômicas tendem a se mover, porém nunca é atingido. Assim, a economia praxeológica concentra-se não no equilíbrio, mas no processo de mercado que leva a ele. Como o processo de transferir recursos para atender esses fins não pode ser atingido espontaneamente, o empreendedorismo tem um papel central. Na visão de Mises e Rothbard, o empreendedorismo envolve incerteza, indo além do estado de alerta enfatizado por Hayek e Kirzner. Por outro lado, diferentemente de Lachmann, que analisa a economia como um caleidoscópio e rejeita a economia uniformemente circular, Mises e Rothbard a consideram uma ferramenta indispensável para entender a economia.
\end{abstract}

Palavras-chave: economia uniformemente circular, praxeologia, empreendedorismo, processo de mercado, equilíbrio.

\section{Emprendimiento y Equilibrio}

Resumen: La teoría económica neoclásica considera el equilibrio, ya sea en forma general o parcial, como un importante fundamento de la ciencia lúgubre. En opinión de los economistas de la corriente principal, el marco de equilibrio general ofrece no solo una investigación de la economía en términos de sus cualidades perfectas, sino también es adecuado como fin o meta de acción. La escuela austríaca, por el contrario, ve el equilibrio (o la economía de rotación uniforme - ERE) simplemente como un tendencia de las actividades económicas para movernos en esa dirección, pero nunca se alcanza. La economía praxeológica se ha concentrado, por lo tanto, no en el equilibrio, sino en el proceso por el que el mercado se mueve hacia ella. Debido a que el proceso de transferencia de recursos para satisfacer estos fines no se pueden alcanzar de forma espontánea, el emprendimiento juega un papel clave. En opinión de Mises y Rothbard, el emprendimiento implica una carga de incertidumbre que va más allá del estado de alerta enfatizado por Hayek y Kirzner. Por otro lado, a diferencia de Lachmann, quien ve la economía como un caleidoscopio y rechaza la ERE, Mises y Rothbard consideran la ERE como una herramienta indispensable para entender la economía.

Palabras clave: Economía de rotación uniforme, praxeología, emprendimiento, Proceso de mercado, equilibrio. 


\section{Introduction $^{1}$}

By using a series of equations, Arrow-Debreu (1954) shows that the maximizing behaviors of individuals can achieve a determinate solution. In order to achieve general equilibrium, there are some necessary conditions. For example, (i) market participants have full relevant knowledge, and (ii) tastes, technology, and resources must be held constant (KALDOR, 1972). The competitive equilibrium has a normative implication as important as the solution, that is, it is Pareto optimal' ${ }^{2}$. Rothbard (2009 [1962], p. 328) argues that mathematical economists treat equilibrium not only as a real - but also as an ideal - state of affairs. ${ }^{3}$ Koppl (1995) stated that the pure science of the Walrasian general equilibrium framework not only can investigate the economy in terms of its ideal qualities, but also is suitable as an end or goal of action. In the view of mainstream economic theory, since perfect competition can cope with individual utility functions and with Pareto optimality, it can discern the level of aggregate welfare. In other words, general equilibrium is used as a benchmark to investigate policies for reform. Walras was by no means a supporter of laissez-faire economics. He believed that there were severe shortcomings in the market mechanism and that government intervention was therefore justified. In particular, he favored income and wealth redistribution and thought government provision of public services indispensable in society. For him, all these matters can best be studied within the framework of general equilibrium (TIEBEN, 2012, p. 256).

Just five years before Arrow and Debreu examined general equilibrium mathematically under the Walrasian system, Ludwig von Mises (2008 [1949]) proposed an alternative concept of equilibrium, named the Evenly Rotating Economy, as an important tool to understand the changing world". Murray N. Rothbard (2009 [1962]) used the ERE in his masterpiece "Man, Economy and State." In introducing this term, Mises was not proposing a new method for describing economic activities. Instead, he merely proposed to use a more accurate phrase to describe the method economists had always used but failed to appreciate (GUNNING, 2005, p. 123). In this way, Mises emphasizes the logical meaning of equilibrium, not its mathematical articulation. In the praxeological definition, acting man is always trying to pursue his goals with certain means, so one cannot conceive of a point in time when every human being stops deliberating and acting. He only stops when all uneasiness has been removed or removing it is out of the question, e.g., too costly. For comparative analysis, the factors that influence human action are all fixed under ceteris paribus conditions: no technology nor preferences change, there are no supply shocks, being a world without uncertainty. Thus, there is no longer any

\footnotetext{
${ }^{1}$ We thank an anonymous referee who greatly helped improve this paper. Or course, all remaining errors and infelicities are solely the responsibility of the authors.

${ }^{2}$ This is the first fundamental theorem of welfare economics (TAN, 2008).

${ }^{3}$ On the contrary, Rothbard regards equilibrium as only a mental concept enabling us to analyze the market and commercial activities. Instead of thinking of it as an ideal state, Rothbard regards the existence of final equilibrium as "most unfortunate" (ROTHBARD, 2009 [1962], p. 323), since it implies every want has been satisfied, and because no change would happen, no further want-satisfaction would be possible.

${ }^{4}$ Mises constructed this concept in "Human Action", released first in German in 1940, later in English, in 1949.

${ }^{5}$ Choosing to go to sleep is an economic act. Falling asleep is not a purposeful human action, no more than is sneezing.
} 
action, whether because all uneasiness has been removed or there is no room for anybody to be better off. Garrison (1991, p. 95) indicated that, in the evenly rotating economy ${ }^{6}$, there is a "complete coordination of all economic activities".

Cowen and Fink (1985) criticized the Mises-Rothbard equilibrium concept in the following ways: first, the ERE implies a "tendency" to equilibrium, given the data-values, technology, and resources. However, the same coordination constraints of general equilibrium should govern the ERE. They denied the convergence tendency of the ERE for reasons relating to coordination problems, such as sequential transactions, income effects, disequilibrium production, consumption, nonconvexities, strategic behavior, and potentially false price signals (COWEN; FINK, 1985, p. 867). In sum, the ERE state is a world with frozen data; however, they claim, the explanation of the tendency towards the ERE when the data are not frozen is insufficient. In the ERE, prices have no function in coordinating behaviors, because all plans are already coordinated, and actors possess all relevant information. In the ERE, prices are merely ex-post ratios, and there is no place for ex-ante prices from disequilibrium situations, which communicate knowledge. Since the ERE lacks market institutions such as prices, interest rates, firms, it can offer little explanation of how the economy reacts to certain exogenous shocks, which the model is supposed to probe into.

Since Mises defines entrepreneurship as uncertainty-bearing, there can be no entrepreneurship in the ERE, given that its purpose is to walk through the logic of an economy without uncertainty. Bylund (2020, p. 356) quotes the relevant passage in Mises: "Consequently, Mises (1998 [1949], p. 247) notes, 'The system [ERE] is in perpetual flux, but it always remains at the same spot. It revolves evenly round a fixed center, and it rotates evenly.' Therefore, there is no uncertainty in the ERE's unchanging world and, consequently, 'there is no room left for entrepreneurial activity'. (MISES, 1998 [1949], p. 247)

What is held constant in the ERE? Rothbard gives a clear answer: "The ERE, per Rothbard, holds four types of changes constant: consumers' value scales, technological ideas used in production, the available supply of resources, and individuals' time preferences. If we were to fix those four variables in the present economy theoretically, an evenly rotating economy would emerge after a period of transition." (BYLUND, 2020, p. 364)

If this is in mind, we can develop a critique of Mises's use of the ERE, which considers issues raised by Hayek and Kirzner, but nevertheless remains true to the essence of Mises's thought. Kirzner and Hayek stress the unrealistic assumptions of the ERE. Doesn't Mises err, they ask, in not considering the effect of learning in changing expectations of entrepreneurs? Instead, he assumes convergence to a purely static equilibrium. However, as Klein (2008, p. 182)

\footnotetext{
${ }^{6}$ Some critics of this concept derisively ask, if there is an evenly rotating economy, what is the time period of the rotation? But this criticism fails because it takes too literally, too narrowly, the word "rotation." In physics, "work" is a function of weight or mass and distance. If an athlete holds two ten-pound bar bells to his side dead still with arms extended, he will do no "work." But his brow will soon begin to sweat and his arms to tremble in exhaustion. This is very heavy work in ordinary language. The critic of the ERE on the ground of time rotation makes a similar error. He is attempting to apply the word "rotation," not "work" where it has a clear meaning in physics, but is misapplied in ordinary language and in Austrian economics. His error is akin to the sort of "physics envy" that compels many economists to hyper-mathematicalize their work.
} 
notes, "Mises does not assume that ERE prices are relevant to the activity of entrepreneurs. It is a purely analytical construct." Klein remarks: Salerno (1991; 1999B) offers a different interpretation of Mises, arguing that Mengerian price theory is primarily a theory of PSR prices, not FSR prices. ${ }^{7}$ From this perspective, the existence or nonexistence of equilibrating tendencies in the unhampered market - the issue that divided 'Kirznerians' and 'Lachmannians' and dominated much of the Austrian discussion in the 1980s - is relatively unimportant. For Mises, the critical 'market process' is not the convergence to equilibrium, but the selection mechanism in which unsuccessful entrepreneurs, who systematically overbid for factors relative to eventual consumer demands, are eliminated from the market."

Given the limited role of the ERE for Mises, the crucial question becomes: what drives entrepreneurs to adjust prices? Here Bylund (2020) offers an essential insight: "what is curious is that Mises at the same time affords the entrepreneur-promoter, a subcategory of entrepreneurship that 'cannot be defined with praxeological rigor' (MISES, 1998 [1949], p. 256), a premier role for understanding the market process". In fact, the promoter embodies, as it were, the incessant change in the market: "One enters the ranks of the promoters by aggressively pushing forward and thus submitting to the trial to which the market subjects [everybody]" (MISES, 1998 [1949], p. 309). In other words, the market process progresses primarily through the actions of promoters, who challenge the status quo. For this reason, 'economics cannot do without the promoter concept' (MISES,1998 [1949], p. 256)".

It is the promoters, thus characterized, who adjust prices to changing economic conditions. "The promoter's role as producer of "great adjustments" to the market's production, as a leader in the social division of labor, is distinct from that of the nonpromoter - and significant" (BYLUND, 2020, p. 375).

Thus, we can conclude that, although Hayek and Kirzner raise valid concerns about ERE being used as a guide to the actual price adjustments of entrepreneurs, these points leave Mises unscathed, given ERE's minimal role in his economics theory. Gunning (2005) tries to absolve Mises from the Cowen-Fink (CF) criticism by emphasizing the logical instead of the mathematical meaning of ERE. He pointed out that CF's criticism is based on a mathematical definition of equilibrium, and not in a logical definition consistent with Mises's pure logic of action". In his words: "In the logical definition, the concept of disequilibrium is meaningless. To say that there is a tendency toward disequilibrium is like saying that individuals do not make choices" (GUNNING, 2005, p. 126). He criticized CF's four criticisms in turn, stressing "entrepreneurship" and "market process" throughout his analysis. However, he did not clarify how entrepreneurship works to move the economy from disequilibrium to the ERE.

\footnotetext{
${ }^{7}$ The PSR means Plain state of Rest, and FSR means Final Stated of Rest.

${ }^{8}$ In fact, the theorists of general equilibrium try to establish a logically consistent mathematical theory in every way possible, as Walras said, "The scholar has a right to pursue science for its own sake, just as the geometer has the right to study the most singular properties for geometric figures, however fantastic, if he finds that they arouse his curiosity" (WALRAS 1954, p. 71-72).
} 
But the answer is straightforward. If entrepreneurs earn a profit, they move us in the direction of the ERE. This is the only logical way "felt uneasiness" can be reduced. Profits are the thermostat of the economy. Bill Gates, Ray Kroc, Henry Ford moved all of us virtually closer to the economic goalposts of consumer satisfaction. However, what of entrepreneurs who suffer losses? Do they not move us in the very opposite direction, that is, toward disequilibrium? This cannot be denied. However, the saving grace for this explanation is that business failures tend to reduce the control over commercial activity on the part of those who suffer them. So, overall, the expectation is for a move in the direction of the ERE. This results from a system wherein those who move us toward the ERE gain revenue, while those who move us in the opposite direction lose economic power. ${ }^{9}$

Ludwig M. Lachmann (1977) rejected both the concept of equilibrium and the ERE. He wrote, "Equilibrium economics studies the full implications of a set of data; it does not study how these logical implications are translated into human action which is thus conceived as a quasi-automatic response to an external stimulus" (LACHMANN, 1977, p. 69). He pointed out that, although each individual tries to maximize his satisfaction, and there is a determinate equilibrium solution, it does not follow that those individuals will succeed in reaching this solution. Since people cannot foresee the future, a plan may fail for many reasons. For this reason, Lachmann rejected the concept of equilibrium or ERE entirely.

Cowen and Fink (1985) and Lachmann (1977) rejected the ERE from different perspectives. Cowen and Fink tried to illustrate that the ERE is inferior to the Debreu equilibrium, claiming that the ERE is "neither a useful substitute for, nor a complement to the standard GE model". Lachmann rejected the ERE and the Arrow-Debreu equilibrium. According to North (2013), "Lachmann was a believer in almost total economic chaos as the basis of economic theory... He called this kaleidic perception. His example of economic entrepreneurship was based on a kaleidoscope, which children look through, turn the base, and see ever-changing but meaningless patterns. He really believed that this is the basis of entrepreneurship".

By making explicit the function of entrepreneurship and the market process in achieving the logic-based concept of the ERE, we will show that it is indispensable to understand economic phenomena and the market economy. The day-to-day world of markets is always moving toward equilibrium ${ }^{10}$, but never quite fully attaining it, ${ }^{11}$ since the determinants of market activities are constantly changing. Therefore, the analysis of the ERE must concentrate on the market process rather than on the final equilibrium state (ROTHBARD, 1995, p. 15). In the following sections, we will try to show the transition mechanism from disequilibrium to equilibrium using entrepreneurship and market process perspectives.

\footnotetext{
${ }^{9}$ Of course, it is equally true that the Gates, the Krocs, the Fords of the world can leave their holdings to their progeny in a free society, and these children may turn out to be poor businessmen, thus directing us toward disequilibrium. But the same insight applies to them: they, too, will suffer losses, and tend to have less sway over the economy than inheritors who are successful entrepreneurs.

${ }^{10}$ Albeit it on an often bumpy path.

${ }^{11}$ There are now over 7 billion people on the planet. A full attainment of equilibrium would imply full and complete cooperation between all of us. It is not quite a logical contradiction to say that this could occur, but such a claim would be mighty close.
} 
In our view, general equilibrium can correctly be criticized based on its rigid mathematical form. In rejecting the imaginary construction of the ERE, we would deny human choice and the efficacy of markets. In Mises's economic analysis, the ERE is a logical outcome of individual action. Mises constructed a pure logic of action. In praxeology, economic actors always pursue means to achieve ends; entrepreneurs continue to act according to their assessment of profit and loss. This logic would rule out the claim that entrepreneurs do not engage in discoveries and do not profit therefrom, but also deny that there is a tendency toward disequilibrium. Denying the existence of the ERE is logically equivalent to repudiating human action.

\section{Entrepreneurship, Market Process and Equilibrium}

\subsection{The ERE as a logical interpretation of equilibrium}

Mises built his economic theory based on praxeology, which is the logical science of human action. In praxeology, human action is purposeful behavior, a person's conscious adjustment to the state of the universe that determines his life. Acting man chooses, determines, and tries to attain a goal. Action is not wishful thinking, nor is it limited to talking about planned but not realized acts; on the contrary, it is a real thing ${ }^{12}$. To engage in action, man must feel a certain kind of uneasiness, and imagine a more satisfactory state that can substitute the present, less satisfactory one. In addition, to act, man must expect that purposeful behavior has the power to remove or, at least, alleviate the felt uneasiness. These are the three prerequisites of human action. Mises stressed that the goals of acting man are subjective, but the means to attain them are objective. Human action is necessarily always rational. However, rationality in this context does not mean the best way to attain the end in question; instead, it means purposeful. In Mises's words, "human reason is not infallible, and man very often errs in selecting and applying means. An action unsuited to the end sought falls short of expectation. It is contrary to purpose, but it is rational" (MISES, 2008 [1949], p. 20).

Based on Praxeology, Mises (2008 [1949]) constructed the evenly rotating economy to describe the state of equilibrium in the economy. He did so in three steps. First, the plain state of rest refers to present prices: in a specific market, people make exchanges until no further exchange is possible because no one expects any further gain at the prevailing price. Second, the final state of rest shows the tendency of prices to change, or future prices. In this state, price is seen as static. These final ${ }^{13}$ prices can never be achieved, because new disturbing factors will emerge before this happens. Although the final state of rest is imaginary and can never be achieved, it is important because the market at every instant is inexorably moving toward $\mathrm{it}^{14}$. Third, the last stage is the evenly rotating economy, characterized by the elimination of

\footnotetext{
${ }^{12}$ However, merely talking about plans is also a human action. On the other hand, automatic bodily functions such as peristalsis, coughing, sneezing, the reflex of the knee when hit by a rubber mallet, etc., while physical, are not considered as part of human action by Austrian economists.

${ }^{13}$ It is idealized, Platonic, theoretical.

${ }^{14}$ An analogy might be apropos at this point. Suppose someone weighs 150 pounds. He jumps on a well-functioning scale, and the needle varies between zero and 300 pounds. If he is still, the oscillations are gradually reduced, until they settle at
} 
all changes in the data and the time element. This would occur if the situation in step 2 were allowed to play out without interruption, without the introduction of exogenous forces. Mises opposed calling the ERE static or stationary; instead, he regarded it as a stable state. In the ERE, the same market transactions are repeated again and again ${ }^{15}$. Its essential character is the elimination of all not fully anticipated changes in the market phenomena.

Rothbard adopts and develops the ERE concept. Mises and Rothbard pointed out that as the data are constantly changing in real life, the economy cannot arrive at an equilibrium. Before attaining it, the economy will shift direction towards some other final equilibrium point. However, even though it is never reached in practice, it is still a crucial concept in economic analysis. We use the imaginary construction of the ERE to analyze the tendency prevailing in every action; however, we should keep in mind that this tendency can never be attained ${ }^{16}$.

Mises stressed that although the market price can never coincide with the final price in the ERE, the ERE is still essential for analyzing economic changes. In the market economy, the changes that determine the formation of prices do not work themselves out instantaneously; a certain amount of time must elapse before all their effects are incorporated. By stressing the dynamic character of the ERE, it is natural to introduce the market-activating concept of entrepreneurship. As Rothbard (2009 [1962], p. 321) indicates, we have two successive states of affairs in the economic system: one is the transition period to an unchanging, evenly rotating economy; the second, the unchanging ERE itself. During this process, entrepreneurship and the profit and loss system play an essential role, "the various complementary factors of production cannot come together spontaneously. They need to be combined by the purposive efforts of men aiming at certain ends and motivated by the urge to improve their state of satisfaction" (MISES, 2008 [1949], p. 249). How does entrepreneurship work to achieve the ERE? Israel M. Kirzner's works make an outstanding contribution to answering this.

\subsection{Entrepreneurship, market process, and the ERE}

Kirzner (1967) pointed out the failures of the mathematical-based neoclassical equilibrium ${ }^{17}$. He maintained that the equilibrium conditions are determined, first, by the data available before the change and, second, by the changed data. The data change brings about an instantaneous jump from the old equilibrium situation to the new one. Even the most advanced work of mathematical economists trying to tackle the dynamic or transitional path to these

his true weight. But, if he jogs on the scale, sometimes creeping along smoothly and, on other occasions, jumping high in the air, as long as he continues this practice, the needle will not settle at the 150-pound indicator. Instead, it will continue to jump all over the place. But there will still be a tendency for it to arrive at his accurate weight. Whereas if a 200-pound man were doing the same thing, then that weight, not 150 pounds, would be the weight toward which the scale would be tending.

${ }^{15}$ The movie “Ground Hog Day” (https://www.imdb.com/title/tt0107048/) is Hollywood's contribution to the ERE.

${ }^{16}$ Other analogies come to mind. In Euclidian geometry, a line has extension but no width. A point has neither. No one can draw either of these. Yes, they are integral to that mathematics. Similarly, there are no perfect gases nor fully frictionless systems. We don't say physics would be entirely lost without them, but a great deal of wind would be taken out of its sails discipline.

${ }^{17}$ Also see Kirzner (1973) in this regard. 
equilibriums was still inadequate to probe into the market process: "this preoccupation has led economists to ignore the character of the market agitation through which decisions are continually being reshuffled toward equilibrium. It has led them to overlook the vital role played by the entrepreneur in the market process" (KIRZNER, 1969, p. 787-788).

For the Austrian school, what matters is not the configuration of prices and outputs, but the tendency toward equilibrium. This refers to the pattern of market adjustments set in motion by conditions of disequilibrium. Kirzner (1969, p. 787) indicated that, "the unique function of the market process is its ability to disseminate scattered pieces of information to those pivotal decision-makers to whom they are most relevant. On the other hand, the state of equilibrium corresponds to the cessation of this process, all relevant knowledge having already become universal".

F. A. Hayek (1949) analyzed the process of how individuals form and adjust their expectations and compared the sequence of adjustments with the state of affairs that prevails under equilibrium. In Hayek's view, everybody undertakes action according to his expectations which are, in turn, influenced by other people's actions. These actions are based on the expectation of the same set of external facts. So, under certain conditions, nobody will have any reason to change his plans, "Correct foresight is then not, as it has sometimes been understood, a precondition which must exist in order to arrive at equilibrium. Rather, it is the defining characteristic of a state of equilibrium" (HAYEK, 1949, p. 42). In other words, individuals acquire new knowledge in the market and continue to adjust their actions according to the contacts between them. So, the market process contains continuous changes in the data for the different individuals. Equilibrium tends toward a state of rest that involves continuous adjusting of individual plans, rather than a fixed series of data.

In the Austrian tradition, the individual decision-maker is inherently active, continually taking action to make himself better off in a way that is essentially different from the resourcesallocation dynamic in neoclassical economics. Purposeful human action is not only about engaging in calculation and resource-allocation, but also involves venturing, innovating, exploring, and searching to ascertain the best course of action. Acting man is not tackling a problem in a given environment. Instead, he has to foresee the appropriate means and ends by continually searching for new information. Even if a man has achieved his immediate ends as a result of the action, he is still alert for possible changes in circumstances. The real world does not consist of fixed ends and means, which are the prerequisite of economizing in the general equilibrium setting, and of external conditions such as tastes; new information constantly appears, altering the way decision-makers consider means and ends. Decisionmakers often seek new information before taking action. They adjust or even replace their former decision according to changing exogenous phenomena. In this sense, entrepreneurs are never price-takers ${ }^{18}$; instead, they play a crucial role in discovering and exploiting hitherto unknown profit opportunities.

${ }^{18}$ This is the diametric opposite viewpoint to mainstream economics, which makes a sharp distinction between price takers (perfect competition) and price searchers (imperfect competition or monopoly). For the Austrian critique of this perspective see Andersen et al.(2001), Armentano (1972; 1982; 1989; 1999), Barnett et al. (2005; 2007), Block, (1977; 1982; 1994), 
In sum, the Austrian analysis of the individual goes beyond rigid economizing economic actors. They are not only endowed with the ability to "mold given means to suit given ends, but with the drive and alertness necessary for their discovery as well. Austrians point to the possibility of an entire logically unified sequence of decisions" (KIRZNER, 1969. p. 791). In other words, they favor a systematic market process with an entrepreneurial element other than the disconnected series of discrete decisions in the neoclassical setting.

However, although Kirzner stressed the role of entrepreneurship and the market process in the transition from disequilibrium to equilibrium, he overlooked potential losses. His "pure" entrepreneurs were not risk bearers and could not possibly suffer any losses. Rothbard comments on Kirzner, "If superior alertness accounts for entrepreneurial profit, what in the Kirznerian world can account for entrepreneurial losses? The answer is nothing" (ROTHBARD, 1995, p. 14).

\section{Uncertainty, Expectation, and Equilibrium}

\subsection{Mises on uncertainty, expectation and equilibrium}

Neoclassical economics assumes that perfectly competitive market participants consumers, producers, suppliers, workers, borrowers, lenders, investors, and firms - all have perfect knowledge regarding all economic variables: demand, supply, costs, prices, technologies, etc., which are crucial for them to make decisions ${ }^{19}$. The newly-developed rational expectation theories pushed these assumptions even further, claiming that market participants not only have perfect knowledge of all present conditions, but also about all future parameters. As a result, we have an omniscient market mechanism. Lucas (1975) and Lucas and Prescott (1971) incorporated rational expectations into equilibrium analysis and regarded rational expectations as the outcome of some unspecified process of learning and adapting of economic participants. In contrast, praxeology states that knowledge of the present, much less of the future, is never perfect. The world in general, and the market, in particular, are eternally marked by uncertainty (ROTHBARD, 1995, p. 10).

Individuals face unexpected obstacles in the course of execution of a planned action. People may misjudge the extent and efficiency of their resources. Mises (2008 [1949], p. 105) stated that, "the uncertainty of the future is already implied in the very notion of action. That man acts and that the future is uncertain are by no means two independent matters. They are only two different modes of establishing one thing".

Mises recognized that the future is hidden for acting man. In other words, whether economic actors turn out to have adopted the most appropriate plan depends on the development

Block and Barnett (2009), Boudreaux and DiLorenzo (1992), Costea (2003), DiLorenzo (1996, 1999; 1985), DiLorenzo and High (1988), Henderson (2013), High (1984; 1985), Hull (2005), McChesney (1991), McGee (1958), Rothbard (2004), Shugart (1987), Smith (1983), Tucker (1998A; 1998B).

${ }^{19}$ Worse, all too often as in the case of monopoly theory, perfect competition is held as the goal, and all deviations from it invite anti-trust scrutiny. For a critique of this neoclassical viewpoint, see page 18. 
of future conditions, which at the time of the plan's execution cannot be forecast with certainty (MISES, 2008 [1949], p. 106). For him, if people's plans fail, they have to reevaluate their expectations to form new plans. Usually, a successful plan is based on expectations that are compatible with those of others, particularly suppliers, buyers, workers. Multiple rounds of this trial and error process make the expectations of different individuals converge to achieve a general equilibrium state, at least theoretically, assuming ceteris paribus.

\subsection{Lachmann on uncertainty, expectation, and equilibrium}

According to Lachmann, some forces make the convergence of expectations impossible to achieve, including exogenous knowledge changes and endogenous resource reallocations. To achieve general equilibrium, economic actors must not only have a continuing constant knowledge of tastes and resources, but also this must be common knowledge, which means everybody shares the same knowledge. However, in a kaleidic or real-world, information is constantly changing, making it very difficult to even conceive of a determinate equilibrium.

Lachmann views economic actions as aiming toward the future and guided by plans. They are far from being strictly determined by a set of objective "data". Instead, they are often decided upon through a process of doubt and uncertainty, vague hopes, and inarticulate fears. Furthermore, final decisions depend on "mental alertness, ability to read the signs of a changing world, and readiness to face the unknown" (LACHMANN, 1943, p. 12). In other words, people draw a mental picture of the situation in which they will act and make their decision based on their interpretation of economic signs. Different people presumably have different interpretations of the same economic phenomena and form different expectations, especially in a dynamic world. This is because "every view of a situation necessarily implies a judgment on the character of the forces producing and governing motion" (LACHMANN, 1943, p. 17). In this sense, expectations have a crucial role in human action, including trying to reach equilibrium.

In Lachmann's view, there is a "filter" effect between observable events and expectations. The expectations respond to people's past experiences, which are largely governed by how individuals interpret them. This interpretation reflects what diverse people believe to be the major forces in operation in a changing world, but it is subjective. Boettke et al. (1986, p. 65) pointed out that once we add the role of judgment to alertness, expectations get full force, and the satisfaction of some individuals' expectations can come only at the expense of the disappointment of others.

Lachmann extended subjectivism from "subjective preferences" (static subjectivism) to "subjective expectations" (dynamic subjectivism), and regarded this extension as a significant leap forward of the subjectivist revolution of the late nineteenth century (LACHMANN, 1994, p. 207-210). Under a subjective expectations analysis, an individual's expectations in reaction to change can vary substantially. As a result, whether a price change or an alteration in any other observable event can give rise to identical expectations will largely depend on how people interpret it. Since different people can have starkly different interpretations of the 
same economic situation, this leads to different estimations of future prices. Lachmann was highly skeptical of the possibility of reaching a state of equilibrium in the real world ${ }^{20}$ and even rejected any role for this concept as a theoretical construct. In Lachmann's disequilibrium account, subjective expectations play a key role in the difficulty to reach equilibrium.

Rothbard (1995, p. 7) stated that Lachmann pushed subjectivism to an unwarranted extreme, "The 'spontaneous order' paradigm of Hayek and the more extreme 'ultra-subjectivist' or nihilist paradigm of Lachmann have both been fallacious and pernicious." Although acting man evaluates products subjectively, Lachmann mistakenly neglects the objective fact that physical objects are being produced and exchanged. Rothbard (1995, p. 9-10) argued that "In value theory, the non-Misesians, especially the Lachmannians, neglect or deny the objective fact that physical objects are being produced, exchanged, and evaluated, albeit that they are subjectively evaluated by acting individuals". Rothbard does not deny that subjectivism is closely connected to the problem of knowledge and uncertainty. Neoclassical economics believes that all market participants have perfect knowledge of economic information related to the economy, such as demands, supplies, prices, costs, among others, at least in their perfectly competitive model. This, of course, is one of the essential prerequisites for general equilibrium.

In contrast, Austrians acknowledge that uncertainty is eternal. Acting man has imperfect knowledge of the present ${ }^{21}$, even less of the future. He thus has to take pains to acquire relevant knowledge. Furthermore, it is the task of the entrepreneur to meet uncertainty by assuming risks, in search of profit, and avoiding loss. "Over time, entrepreneurs who are successful in bearing risks and forecasting their particular future will earn profits and expand their operations, while poor risk-bearers and forecasters will suffer losses and necessarily shrink their field of activity" (ROTHBARD, 1995, p. 11). Therefore, entrepreneurs must be alert to risks and be successful more often than not in their forecasts ${ }^{22}$. The Misesian man knows economic laws, but does not know everything about resources, tastes, recipes. He must try to foresee the future, quantitatively and qualitatively. However, although Mises admits the uncertainty faced by the entrepreneurs, his view is quite different from Lachmann's radical uncertainty and nihilism, "But in contrast to this 'moderate 'uncertainty of Misesian Man [is] the plight of Lachmannian Man, subject to Lachmann's radical uncertainty and nihilism" (ROTHBARD, 1995, p. 11). In Lachmann's view, the acting man knows nothing about the future; he can only imagine it. As a result, Lachmannian man steps into a trackless void, and Lachmann himself regarded the concept of equilibrium as entirely meaningless.

In contrast, Mises emphasized that the ERE state is merely a tool for our thinking, "it is not the description of a possible and realizable state of affairs; it is even out of the question to carry the imaginary construction of an evenly rotating system to its ultimate logical consequences" (MISES, 2008 [1949], p. 249). Rothbard emphasized that, although the ERE is the goal toward

\footnotetext{
${ }^{20}$ An assessment he shares with all Austrian economists.

${ }^{21}$ Not all that much about the past.

${ }^{22}$ Translation: they must not suffer losses and go bankrupt. They can afford many short-term losses, as long as a few successes hurl them back into the black.
} 
which the economy is moving at any particular time, economic forces continually change this position and therefore shift the direction of the movement.

\section{Conclusion}

Although, in reality, there is no such thing as an Evenly Rotating Economy, the construction of this concept is essential to the analysis of the uneven and irregular changes in the real world ${ }^{23}$. It is only in the ERE that we can eliminate the role of entrepreneurship. People just repeat their actions again and again without the need to cope with uncertainty. Therefore, examining a world in which there is neither uncertainty nor entrepreneurship helps shed light on the nature of entrepreneurship in the real world. For instance, in the real world, entrepreneurs have to decide which products should be produced and shift resources and factors according to profit and loss. The process of shifting resources to meet profitable ends cannot be achieved spontaneously. Entrepreneurship plays a key role. In addition, the ERE can serve as a starting point to examine the effect of external shocks. Mises indicates that if we wish to analyze the effects of an exogenous shock upon the economic system, we start with a state where there is no change and then allow the new change to work its way through the system until the economy settles into equilibrium again. By comparing the two equilibria, we can see the shock effects (MISES, 2008 [1949], p. 247).

The general equilibrium of neoclassic economics is regarded as an optimal state yielding efficiency. If the real economy is not in this state, this gives rise to their concept of "market failure." They deduce from this that it is then legitimate for the government to correct this situation. ${ }^{24}$ This misconstrues the function of the ERE. As Rothbard indicated, “... a final equilibrium is the goal toward which the economy is moving at any particular time, changes in the data alter this position and therefore shift the direction of movement. Therefore, there is nothing in a dynamic world that is ethically better about a final equilibrium position" (ROTHBARD, 2009 [1962], p. 323).

Furthermore, he pointed out the mistake of interpreting the condition of zero profits and losses in the ERE as the condition for legitimate activity on the market. Instead of calling equilibrium "optimal," Rothbard thought it as "most unfortunate" since no change would occur and no further want satisfaction would be possible (ROTHBARD, 2009, [1962], p. 323). In this respect, entrepreneurs have more critical roles than detecting disequilibrium; they are also called upon to break up conditions close to equilibrium and create more market opportunities.

Likewise, Kirzner (1967; 1987) indicated that for the neoclassicals, the equilibrium approach of price theory has not only a positive meaning, but also a normative implication,

\footnotetext{
${ }^{23}$ The first cousin of the ERE is the ceteris paribus assumption. In reality, neither of these can ever be relied upon; they can never be attained. But as heuristic devices, as theoretical constructs, both are essential for economic analysis. Indeed, it is difficult to see how economic analysis could be done without them, apart from empirical econometric work. We do not have any rigidly controlled experiments in the real world. Austrian economists, at least, are reduced to thinking about them, through such means as the ERE and ceteris paribus.
}

${ }^{24}$ In doing so, they erroneously deduce an "ought" from an "is." 
"The efficiency of the market is judged by the pattern of prices, outputs, allocation of resources prevailing under equilibrium conditions. All institutions, or utilization of resources, that may be present in the real world, which do not correspond to the efficient pattern of resource allocation required of the equilibrium, are immediately stamped as inefficient".

Moreover, the preoccupation with equilibrium also has been used by Lange-Lerner (1936; 1937 ) to challenge Mises's claim that central planning is impossible ${ }^{25}$. The mistake of these authors arose from their misuse of the concepts of equilibrium and market process. Based on their preoccupation with the equilibrium system as a real-world desideratum, instead of a theoretical construct, they concluded that the economic problem facing society consists of nothing more than allocating resources on the assumption of perfect information. Namely, they posited that market participants possess the relevant information concerning preferences, technological possibilities, and resource availabilities. According to Lange (1938, p. 60), "The economic problem is a problem of choice between alternatives. To solve the problem three data are needed: (1) a preference scale which guides the acts of choices; (2) knowledge of the "terms on which alternatives are offered"; and (3) knowledge of the number of resources available".

Those three data being given, the problem of choice is soluble... a careful study of price theory and production theory convinces us that, given the data from 1 and 3 , the "term on which alternatives are offered" is determined ultimately by the technical possibilities of transformation of one commodity into another, i.e., by the production functions. The administrators of a socialist economy would have precisely the same knowledge, or lack of it, of the production functions the capitalist entrepreneurs have. If this were true, the economic problem of allocating resources would be reduced to a mere computation. Lange reasoned that the same solution is attainable both via market equilibrium and by central planners. He argued that the equilibrium problem in a competitive market could be solved by trial and error (LANGE, 1938, p. 70). However, in the real world, preferences are constantly changing, and information acquisition is also costly.

In sum, the imaginary constructions of the ERE in Austrian economic analysis function as the praxeologist's unique substitute for laboratory experiments of the physical sciences (ROTHBARD, 1995, p. 16). Since the ceteris paribus condition cannot hold in the real economy, the construction of the ERE is a laboratory for a thought experiment. In Rothbard's view, a consistent refusal to employ equilibrium concepts would make it impossible for us to understand economic law.

Rothbard also pointed out that paying too much emphasis to the market process, to the neglect of the ERE, would lead to a failure to understand the "processes" themselves fully. Although Hayek and Kirzner have preserved the concept of equilibrium, their theories are mainly based on empirical rather than praxeological grounds (ROTHBARD, 1995, p. 17-18). In contrast, Lachmann's market process stressed impersonal mechanisms rather than the conscious goal-directed human actions (ROTHBARD, 1995, p. 17). Therefore, the two theories diverge from each other due to their different claims about the pace of exogenous changes and

${ }^{25}$ For the claim that socialist planning is not just inefficient, but actually impossible see Mises (1922). 
people's learning. Hayek claims that entrepreneurs are learning at a faster pace than the data are changing. Lachmann, to the contrary, deems that data are changing faster than people can learn. As a result, they reach different conclusions (ROTHBARD, 1995, p. 18).

Mises and Rothbard do not look at equilibrium empirically; it is not a horse race for them. Instead, they analyze the ERE from the perspective of praxeology. They see purposive and goal-oriented human actions as the essential component of the market process. This implies equilibrium as a quintessential application of logic, even if the state is never fully reached.

\section{References}

ANDERSON, William et. al. The Microsoft Corporation in Collision with Antitrust Law. The Journal of Social, Political and Economic Studies, v. 26, n.1, 2001.

ARMENTANO, Dominick T. The Myths of Antitrust. New Rochelle: Arlington House, 1972.

ARMENTANO, Dominick T. Antitrust and Monopoly: Anatomy of a Policy Failure. New York: Wiley, 1982.

ARMENTANO, Dominick T. Antitrust Reform: Predatory Practices and the Competitive Process. Review of Austrian Economics, v. 3, 1989.

ARMENTANO, Dominick T. Antitrust: The Case for Repeal. Auburn: Mises Institute, 1999.

ARMSTRONG, Don. Competition vs. Monopoly. Vancouver: The Fraser Institute, 1982.

ARROW, Kenneth J.; DEBREU, Debreu. Existence of an Equilibrium for a Competitive Economy. Econometrica, v. 22, n. 3, p. 265-290, 1954.

BARNETT, William II; BLOCK, Walter E.; SALIBA, Michael. Predatory pricing. Corporate Ownership \& Control, v. 4, n. 4, 2007.

BARNETT, William; BLOCK, Walter E.; SALIBA, Saliba. Perfect Competition: A Case of 'Market-Failure. Corporate Ownership \& Control, v. 2, n. 4, p. 70-75, 2005.

BLOCK, Walter; BARNETT, William. Monopsony Theory. American Review of Political Economy, v. 7, n. 2, 2009.

BLOCK, Walter E. Austrian Monopoly Theory -- a Critique. The Journal of Libertarian Studies, v. 1, n. 4, p. 271-279, 1977.

BLOCK, Walter E. Amending the Combines Investigation Act. Vancouver: The Fraser Institute, 1982.

BLOCK, Walter E. Total Repeal of Anti-trust Legislation: A Critique of Bork, Brozen and Posner. Review of Austrian Economics, v. 8, n. 1, 1994.

BOETTKE, Peter J.; HORWITZ, Steven; PRYCHITKO, David L. Beyond equilibrium economics: reflections on the uniqueness of the Austrian tradition. Market Process, v. 4, n. 2, p. 6-25, 1986.

BOUDREAUX, Donald J.; DILORENZO, Thomas J. The Protectionist Roots of Antitrust. Review of Austrian Economics, v. 6, n. 2, p. 81-96, 1982.

BYLUND, Per L. Finding the Entrepreneur-Promoter: A Praxeological Inquiry. Quarterly Journal of Austrian Economics, v. 23, n. 3-4, p. 355-389, 2020.

COATS, A.W. Is there a 'structure of scientific revolutions' in Economics? Kyklos, v. 22, n. 2, p. 289-296, 1969. 
COSTEA, Diana. A Critique of Mises's Theory of Monopoly Prices. The Quarterly Journal of Austrian Economics, v. 6, n. 3, 2003.

COWEN, Tyler; RICHARD, Fink. Inconsistent Equilibrium Constructs: The Evenly Rotating Economy of Mises and Rothbard. The American Economic Review, n. 75, v. 4, 1985.

DILORENZO, Thomas J. The origins of antitrust: an interest-group perspective. International Review of Law and Economics, v. 5, 1985.

DILORENZO, Thomas J. The Myth of Natural Monopoly. Review of Austrian Economics, v. 9, n. 2, 1996.

DILORENZO, Thomas. The Truth about Sherman. November, 1999. Available: https://mises.org/library/truthabout-sherman. Acessed: Jan 12020.

DILORENZO, Thomas J.; HIGH, Jack. Antitrust and Competition, Historically Considered. Economic Inquiry, v. 26, n. 1, 1988.

GARRINSON, Roger. New Classical and Old Austrian Economics: Equilibrium Business Cycle Theory in Perspective. Review of Austrian Economics, v. 5, n. 1, 1991.

GUNNING J. Patrick. Mises on the Evenly Rotating Economy. The Review of Austrian Eco, v. 3, n. 1, 1989.

HAHN, F.H. Equilibrium and Macroeconomics. Oxford: Basil Blackwell, 1984.

HAYEK F. A. Individualism and Economic Order. London: Routledge and Kegan paul, 1949.

HENDERSEN, David R. The Robber Barons: Neither Robbers nor Barons. The Library of Economics and Liberty, March, 2013. Available at: https://www.econlib.org/library/Columns/y2013/Hendersonbarons.html. Acessed: Jan 12020.

HICKS, J.R. Value and Capital: An inquiry into some fundamental principles of economic theory. Oxford: Clarendon, 1939.

HIGH, Jack. 1984-1985. Bork's Paradox: Static vs. Dynamic Efficiency in Antitrust Analysis. Contemporary Policy Issues, v. 3, p. 21-34, 1939.

HULL, Gary. The Abolition of Antitrust. New Brunswick: Transaction Publishers, 2005.

KALDOR, Nicholas. The Irrelevance of Equilibrium Economics. The Economic Journal, v. 82, p. 1237-1255, 1972.

KIRZNER, Israel M. Methodological Individualism, Market Equilibrium, and Market Process. IL Politico, v. 32, n. 4, p. 787-799, 1967.

KIRZNER, Israel M. Competition and Entrepreneurship. Chicago: University of Chicago Press, 1977.

KLEIN, Peter G. The Mundane Economics of the Austrian School. Quarterly Journal of Austrian Economics, v. 11, n. 1, p. 165-187, 2008.

KOPPL, Roger. The Walras Paradox. Eastern Economic Journal, v. 21, n. 1, p. 43-55, 1995.

LACHMANN, Ludwig M. The Role of Expectations in Economics as a Social Science. Economica, v. 10. n. 37, p. 12-23, 1943.

LACHMANN, Ludwig M. Carl Menger and the Incomplete Revolution of Subjectivism. In: Expectations and the Meaning of Institution. Don Lavoied. London: Roubledge, 1994. 
LANGE, Oskar, R. On the Economic Theory of Socialism. On the Economic Theory of Socialism, Minnesota: University of Minnesota press, 1938.

LAWSON, T. The (confused) State of Equilibrium Analysis in Modern Economics: an explanation. Journal of Post Keynesian Economics, v. 27, n. 3, p. 423-444, 2005.

LERNER, Abba. Statics and Dynamics in Socialist Economics. The Economic Journal, v. 47, n.186, p. 253-270, 1937.

LUCAS, Robert. E. Asset Prices in an Exchange Economy. Econometrica, v. 46, p. 1429-1445, 1978.

LUCAS, Robert.E., Jr.; PRESCOTT. C. Investment under uncertainty. Econometrica, v. 39, p. 659-681, 1971.

MARSHALL, Alfred. Principles of Economics. London: Macmillan, 1920.

MCCHENEY, Fred. Antitrust and Regulation: Chicago's Contradictory Views. Cato Journal, v. 10, n. 3, 1991.

MCGEE, John S. Predatory Price Cutting: The Standard Oil (New Jersey) Case. The Journal of Law and Economics, v. 1, 1958.

MISES, Ludwig von. Socialism: An Economic and Sociological Analysis. Indianapolis: Liberty Fund, 1981 [1922].

MISES, Ludwig von. Human Action. London: Mises Institute, 1949.

NORTH, Gary. Tenured Austrian Economists vs. Murray Rothbard. Available at: https://www.garynorth. com/public/10768.cfm. Acessed: Jan 12020.

ROSENBARG, A. Economics: Mathematical Politics or Science of Diminishing Returns. Chicago: University of Chicago Press, 1992.

ROTHBARD, Murray N. The Present State of Austrian Economics. Journal des Economistes et des Etudes Humaines, v.6, n. 1, 1995.

ROTHBARD, Murray N. Man, Economy and State. Auburn: Ludwig von Mises Institute, 2004 [1962].

SALERNO, Joseph T. Ludwig von Mises's Monetary Theory in the Light of Modern Monetary Thought. Review of Austrian Economics, v. 8, n. 1, 1994.

SALERNO, Joseph T. Commentary: The Concept Coordination in Austrian Macroeconomics. In: Austrian Economics. Mich: Hillsdale College Press, 1991.

SALERNO, Joseph T. The Place of Mises's Human Action in the Development of Modern Economic Thought. Quarterly Journal ofAustrian Economics, v. 2, n. 1, p. 35-65, 1999.

SHUGHART II, William F. Don't Revise the Clayton Act, Scrap It!. Cato Journal, v. 6, n. 3, 1987.

SAMUELSON, Paul A. Foundations of Economic Analysis. Cambridge: Harvard University Press, 1947.

SMITH, Jr.; FRED, L. Why not Abolish Antitrust?. Regulation, Jan-Feb, v. 23, 1983. Available: http://cei.org/opeds-and-articles/why-not-abolish-antitrust. Acessed: Jan 12020.

TAN, K. The First Fundamental Theorem of Welfare Economics. Chicago, 2008. Available: https://www.math. uchicago.edu/ may/VIGRE/VIGRE2008/REUPapers/Tan.pdf (unpublished). Acessed: Jan 12020.

TIEBEN, Bert. The Concept of Equilibrium in Different Economic Traditions: A Historical Investigation. Massachusetts: Edward Elgar Pub, 2012. 
TUCKER, Jeffrey. Controversy: Are Antitrust Laws Immoral? Journal of Markets \& Morality, v. 1, n. 1, p. 75$82,1998 \mathrm{~A}$.

TUCKER, Jeffrey. Controversy: Are Antitrust Laws Immoral? A Response to Kenneth G. Elzinga. Journal of Markets \& Morality, v. 1, n. 1, p. 90-94, 1998B.

WALRAS, Leon. Elements of Pure Economics, or the Theory of Social Wealth. New York: American Economic Association, 1954.

RECEIVED: 10 MARCH 2021. APPROVED: 7 MAY 2021. 